\title{
Analisa Stabilitas Tubuh Bendungan Utama Pada Bendungan Semantok, Nganjuk, Jawa Timur
}

\author{
Rizki Ramadhani Pratama ${ }^{1 *}$, Heri Suprijanto ${ }^{1}$, Runi Asmaranto ${ }^{1}$ \\ ${ }^{1}$ Jurusan Teknik Pengairan, Fakultas Teknik, Universitas Brawijaya, \\ Jl. MT. Haryono No.167, Malang, 65145, INDONESIA \\ *Korespondensi Email: rizkierpe@ gmail.com
}

\begin{abstract}
By the changes of embankment material and foundation treatment on Semantok Dam, it is necessary to analyze the dam stability. This study aimed to know about the material specification, the geologic conditions \& the foundation treatment, and the dam stability. The specification result shows that core material and fine filter material meet the criteria. The geologic conditions consist of Sand, Sandstone, and Claystone. The alternative for foundation treatment proposed using Secant Pile Cut-Off Wall and Cut-Off Trench. The rock bearing capacity and the core zone settlement is safe. The foundation's elastic deformation is estimated at 3,56 $\mathrm{cm} \sim 4,36 \mathrm{~cm}$. The filtration flow stability using SEEP/W shows seepage discharge, piping, and boiling potential are safe. The slope stability by Bishop method using SLOPE/W shows static condition; OBE 100; and OBE 200 are safe, but MDE 10000 is unsafe. Permanent deformation analysis for MDE 10000 by Makdisi Seed method and Swaisgood shows the deformation is safe.
\end{abstract}

Keywords: Dam, Foundation, Material, Semantok, Stability

Abstrak: Dengan adanya perubahan material timbunan dan perbaikan pondasi pada Bendungan Semantok, perlu dilakukan analisa stabilitas bendungan tersebut. Studi ini bertujuan untuk mengetahui spesifikasi material, kondisi geologi dan perbaikan pondasi, serta stabilitas bendungan. Hasil spesifikasi menunjukkan bahwa material inti dan filter halus memenuhi kriteria. Secara geologi pondasi Bendungan Semantok terdiri dari Pasir, Batu pasir, dan Batu lempung. Alternatif perbaikan pondasi diusulkan menggunakan Secant Pile Cut-off Wal dan Cut-off Trench. Daya dukung batuan pondasi dan penurunan zona inti bendungan aman. Deformasi elastis pondasi sebesar 3,56 $\mathrm{cm} \sim 4,36 \mathrm{~cm}$. Stabilitas terhadap aliran filtrasi dengan SEEP/W menunjukkan debit rembesan, gejala buluh, dan gejala sembulan aman. Stabilitas lereng metode Bishop dengan SLOPE/W menunjukkan kondisi statis, OBE 100, dan OBE 200 aman, tapi untuk MDE 10000 tidak aman. Deformasi permanen untuk MDE 10000 dengan Metode Makdisi dan Swaisgood aman.

Kata kunci: Bendungan, Material, Pondasi, Semantok, Stabilitas 


\section{Pendahuluan}

Dalam strategi "Pengelolaan Sumber Daya Air", diantaranya adalah pembangunan 65 bendungan dan 1.893 buah embung/bangunan penampung air lain [1]. Salah satunya Bendungan Semantok, dibangun untuk menampung aliran air Sungai Semantok yang termasuk dalam DAS Brantas. Pembangunannya ditujukan untuk pemenuhan air baku, suplai irigasi, dan pengendalian banjir.

Beberapa kendala pada pembangunan Bendungan Semantok, diantaranya setelah dilakukan pengeboran, didapatkan bahwa material batu yang disebutkan dalam desain awal sebagai bahan timbunan tidak banyak tersedia di Quarry Area, sehingga desain dan spesifikasi material urugan bendungan harus disesuaikan lagi [2]. Sementara pada pondasi bendungan, setelah dilakukan Trial Grouting, didapatkan bahwa hasil trial grouting tidak efektif, sehingga dilakukan perbaikan pondasi dengan metode lain, yaitu dengan Secant Pile dan Cut-Off Trench. [3]

Dalam perencanaanya, bendungan harus memenuhi syarat keamanan terhadap kegagalan hidrolik, kegagalan filtrasi, maupun kegagalan struktural [4]. Sehingga dilakukan spesifikasi material urugan pada Bendungan Semantok, kajian terhadap kondisi geologi dan perbaikan pondasi Bendungan Semantok, serta analisa terhadap stabilitas Bendungan Semantok diantaranya : stabilitas terhadap daya dukung dan penurunan, aliran filtrasi, dan lereng bendungan.

\section{Bahan dan Metode}

\subsection{Lokasi Studi}

Bendungan Semantok berlokasi di Dusun Kedungpingit, Desa Sambi Kerep, Kecamatan Rejoso Kabupaten Nganjuk Provinsi Jawa Timur. Secara astronomis, bendungan terletak pada koordinat $111^{\circ} 53^{\prime}-25,68^{\prime \prime}$ BT dan 7²9'- 41,90" LS. Bendungan Semantok memiliki luas Daerah Tangkapan Air 54,032 km² dan panjang as 3,005 km.

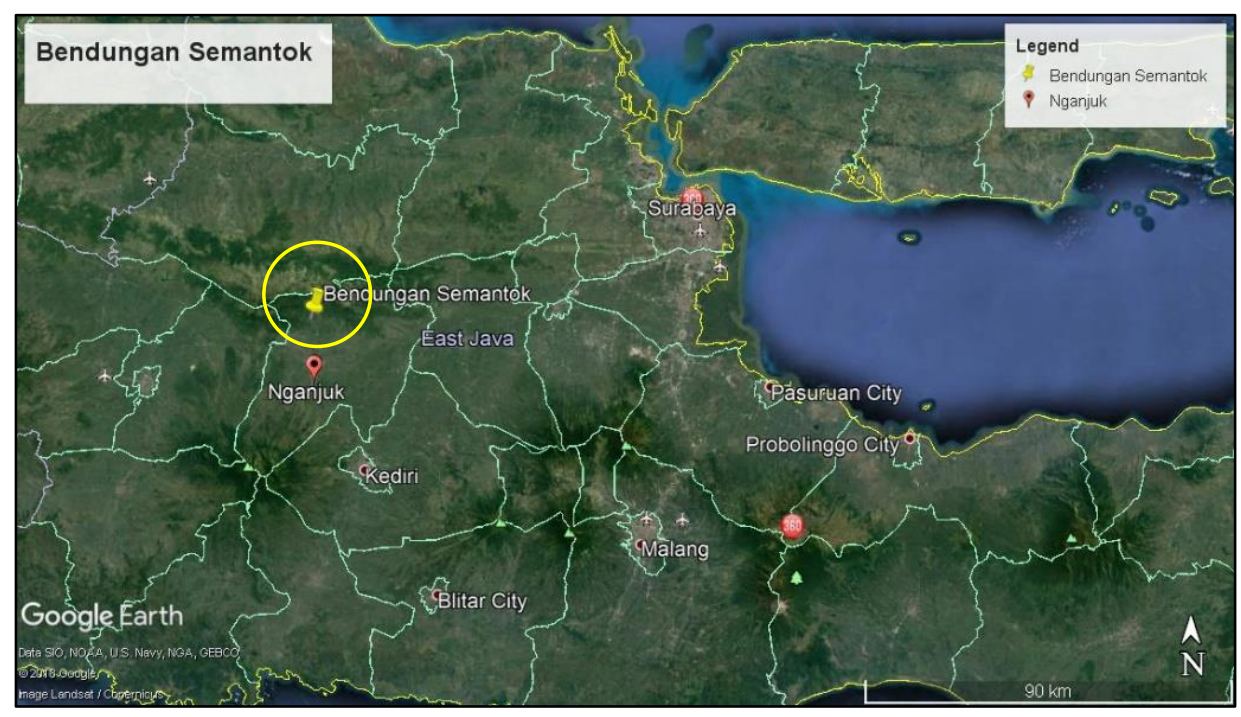

Gambar 1 : Lokasi Bendungan Semantok 
2.2 Alur Pengerjaan

\begin{tabular}{|c|c|c|}
\hline $\begin{array}{c}\text { Pengumpulan } \\
\text { Data }\end{array}$ & $\begin{array}{cl} & \text { Spesifikasi Material } \\
& \text { Timbunan } \\
- & \text { Material Inti } \\
- & \text { Material Filter Halus }\end{array}$ & $\begin{array}{cl} & \text { Kajian Geologi \& } \\
& \text { Perbaikan Pondasi } \\
- & \text { Tegangan Vertikal } \\
- & \text { Penurunan Zona Inti }\end{array}$ \\
\hline \begin{tabular}{ll} 
& \multicolumn{1}{c}{ Analisa Stabilitas } \\
Lereng \\
- & Penentuan Beban \\
& Gempa \\
- & Stabilitas lereng \\
- & Deformasi permanen
\end{tabular} & \begin{tabular}{ll} 
& \multicolumn{1}{c}{ Analisa Stabilitas } \\
& \multicolumn{1}{c}{ Aliran Filtrasi } \\
- & Pola Garis Freatik \\
- & Debit Rembesan \\
- & Gejala Piping dan \\
& Boiling
\end{tabular} & $\begin{array}{ll}\text { Analisa Stabilitas Daya } \\
\text { Dukung \& Penurunan } \\
\text { - } & \text { Tegangan Vertikal } \\
- & \text { Penurunan Zona Inti } \\
- & \text { Penurunan Elatis } \\
& \text { Pondasi }\end{array}$ \\
\hline
\end{tabular}

2.3 Data-data yang Diperlukan

Data-data yang diperlukan meliputi data material timbunan Bendungan Semantok, Summary Gradasi Material Timbunan, Summary Hasil Pengujian Material Timbunan, Bore Log pada as Bendungan Semantok, data hasil Trial Grouting, data geologi Bendungan Semantok, data debit rerata Sungai Semantok, data teknis dan geometri tubuh Bendungan Semantok, dan Peta Gempa 2017. Penampang melintang bendungan ditunjukkan pada Gambar 2.

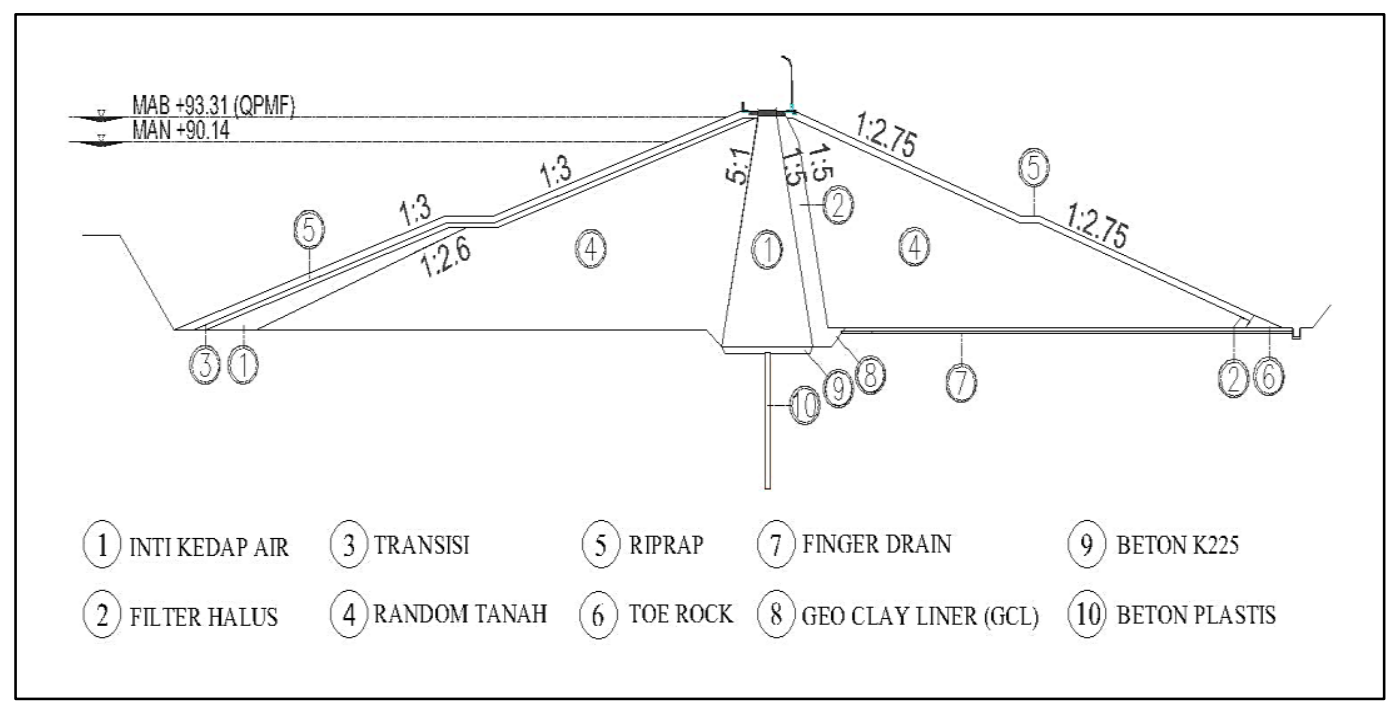

\section{Gambar 2 : Potongan Melintang Bendungan Semantok Sumber : Laporan Akhir Sertifikasi Desain Bendungan Semantok (2018)}

\subsection{Spesifikasi Material Timbunan}

Spesifikasi material timbunan pada studi ini dikhususkan untuk material inti kedap air dan spesifikasi filter halus. Spesifikasi material inti kedap air meliputi regrading base soil [5],plastisitas, kriteria pemadatan, dan permeabilitas [6]. Spesifikasi material filter halus meliputi penentuan batas gradasi material [5], sifat material dan permeabilitas [6]. 


\subsection{Kajian Geologi dan Perbaikan Pondasi}

Kajian terhadap kondisi geologi maupun geoteknik untuk mengetahui karakteristik batuan pondasi di bawah Bendungan Semantok. Kajian terhadap hasil trial grouting menunjukkan karakteristik tanah pondasi dan alternatif pondasi selain metode grouting.

\subsection{Tegangan Vertikal dan Daya Dukung Pondasi}

Pondasi batuan aman jika daya dukungnya memenuhi sebagai tumpuan untuk tegangan vertikal bendungan. Tegangan vertikal dihitung menggunakan teori Boussinesq untuk beban trapesium terbagi merata [7]. Daya dukung batuan dapat diestimasi berdasarkan kelas batuan dengan tabel "Klasifikasi Massa Batuan dan Parameter Batuan" dari Kikuchi [8]. Kekuatan desain daya dukung batuan perlu dikorelasikan dengan RQD [9].

\subsection{Penurunan Zona Inti Bendungan}

Penurunan bendungan sangat tergantung dari karkteristik material yang digunakan. Besar penurunan dapat diperhitungkan dengan rumus empirik [6]. Penurunan yang diijinkan sebesar $2 \%$, dan bila tinggi tubuh bendungan $>30$ meter ditambah $1 \%$ untuk mengantisipasi penurunan akibat gempa [4].

\subsection{Deformasi / Penurunan Elastis Batuan Pondasi}

Perhitungan penurunan elastis untuk mengetahui besar penurunan pada lapisan tanah pondasi kompresibel. Pendekatannya dikembangkan oleh Scleicher dengan Faktor Bentuk dari Winterkorn \& Fang [10]. Pendekatan lain dikembangkan oleh Lord dengan Faktor Bentuk dari Whitman \& Richart; serta Faktor Kedalaman dari Pells Turner [11].

\subsection{Kapasitas Aliran Filtrasi}

Analisa terhadap aliran filtrasi menggunakan Geo-Studio SEEP/W 2018, mengacu pada "Stability Modelling with SEEP/W" dari Geo-Slope International Ltd. Analisa dilakukan untuk kondisi muka air banjir, normal, minimum, dan rapid draw down. Besar kapasitas atau debit rembesan didapat dari flow rate (SEEP/W) dikalikan dengan panjang bendungan. Debit rembesan aman bila Q Rembesan < 1\% Debit Rerata Sungai [12].

\subsection{Gejala Buluh (Piping) dan Sembulan (Boiling)}

Rembesan melalui pondasi dan tubuh bendungan harus dikendalikan sehingga tidak terjadi gaya angkat yang berlebihan [13]. Komponen vertikal dari kecepatan aliran keluar atau kecepatan kritis secara teoritis dikembangkan oleh Justin [6]. Apabila nilai kecepatan rembesan $(V s)<$ kecepatan kritis $(V c)$, maka tidak terjadi gejala piping [14]. Pada pasir, gaya singgung antar partikel nol dan tidak memiliki kekuatan, dan jika $\gamma^{\prime} / \gamma \mathrm{w}$ atau gradien hidrolik kritis $\left(\mathrm{i}_{\mathrm{cr}}\right)$ membesar, permukaan tanah akan mengalami kondisi 'boiling'. Lempung masih memiliki kekuatan pada saat tegangan normal efektif sama dengan nol, sehingga, jika gradien kritis lempung mencapai $\gamma^{\prime} / \gamma \mathrm{w}$ gejala 'boiling' tidak terjadi [15].

\subsection{Penentuan Beban Gempa}

Kriteria kala ulang gempa yang dianalisa tergantung dari kelas resiko bendungan [16]. Untuk kala ulang yang akan dianalisa, besarnya percepatan batuan dasar $\left(\mathrm{S}_{\mathrm{B}}\right)$ didapatkan dari Peta Gempa 2017 [17] dan website pgacal.pusair-pu.go.id. 


\subsection{Analisa Stabilitas Lereng}

Analisa stabilitas lereng menggunakan Geo-Studio SLOPE/W 2018 dengan Metode Bishop, mengacu pada "Stability Modelling with SLOPE/W" yang disediakan Geo-Slope International Ltd. Kondisi berbahaya yang perlu ditinjau antara lain Setelah Konstruksi, Muka Air Banjir, Muka Air Normal, Muka Air Minimum, dan Rapid Draw Down . Pada setiap kondisi, Faktor Keamanan harus memenuhi Faktor Keamanan yang disyaratk an [18]

\subsection{Analisa Alihan Tetap / Deformasi Permanen}

Analisa ini diperlukan apabila pada analisa stabilitas lereng dengan kondisi MDE masih belum memenuhi faktor keamanan yang disyaratkan. Besarnya deformasi permanen I settlement (U) disyaratkan tidak melebihi 50\% dari tinggi jagaan bendungan [16]. Analisa alihan tetap dapat dihitung menggunakan Metode Makdisi Seed dan Metode Swaisgood. Dengan metode Makdisi Seed dibutuhkan parameter ky dan kmax [19]. Jika ky/kmax < 1 maka terdapat Alihan Tetap [16], dan besarnya penurunan didapatkan dari grafik hubungan ky/kmax dan displacement (U) [20]. Dengan metode Swaisgood, prosentase penurunan / deformasi didapatkan dari grafik hubungan PGA, Ms, dan Settlement (\%) [21].

\section{Hasil dan Pembahasan}

\subsection{Spesifikasi Material Bendungan Semantok}

Spesifikasi dilakukan terhadap hasil regrading dan hasil pengujian material inti kedap air. Tabel 1 menunjukkan hasil investigasi dari sampel material inti memenuhi kriteria untuk digunakan sebagai material timbunan inti kedap air.

Tabel 1 : Hasil Spesifikasi Material Inti Kedap Air

\begin{tabular}{|c|c|c|c|}
\hline Kriteria & Hasil Investigasi & Keterangan & Spesifikasi \\
\hline Material gradasi halus & $\begin{array}{c}70,22 \%-82,9 \% \text { lolos } \\
\text { ayakan No.200 }\end{array}$ & Material gradasi halus & Memenuhi \\
\hline $\begin{array}{l}\text { Gradasi butiran material } \\
\text { sesuai range zona inti } \\
(\mathrm{dmax} 4,76 \mathrm{~mm})\end{array}$ & $\begin{array}{l}\text { Gradasi butiran } \\
\text { regraded dengan } \\
\text { dmax } 4,76 \mathrm{~mm}\end{array}$ & $\begin{array}{c}\text { Masuk ke dalam range zona inti } \\
\text { kedap air }\end{array}$ & Memenuhi \\
\hline Bersifat Plastis & \multirow{3}{*}{$\mathrm{MH}, \mathrm{CL}, \mathrm{CH}$} & Plastisitas rendah $\sim$ tinggi & Memenuhi \\
\hline $\begin{array}{l}\text { Tidak mengandung zat } \\
\text { organik }\end{array}$ & & Material bersifat anorganik & Memenuhi \\
\hline $\begin{array}{c}\text { Kualitas sebagai bahan } \\
\text { urugan }\end{array}$ & & $\begin{array}{c}\text { Dapat digunakan sebagai material } \\
\text { inti }\end{array}$ & Memenuhi \\
\hline $\begin{array}{c}\text { Indeks Plastisitas } \\
15 \%-45 \%\end{array}$ & $19,90 \%-40,81 \%$ & $\begin{array}{l}\text { Indeks Plastisitas sesuai batas min, } \\
\text { dan max, }\end{array}$ & Memenuhi \\
\hline Kadar Air $\pm 2-3$ OMC & $\mathrm{OMC}=34,584 \%$ & $\begin{array}{l}\text { Kadar air < OMC, saat penimbunan } \\
\text { dilakukan pemadatan hingga kadar } \\
\text { air berkisar } 31,584 \% \sim 37,584 \%\end{array}$ & Memenuhi \\
\hline $\begin{array}{l}\text { Derajat Kepadatan } \geq \\
\text { 95\% Maximum Dry } \\
\text { Density }\end{array}$ & $\mathrm{D}=95 \%$ & $\begin{array}{c}\text { Nilai } \gamma \text { dry untuk desain } \\
\text { menggunakan } 95 \% \text { dari MDD, saat } \\
\text { penimbunan dilakukan pemadatan } \\
\text { hingga } D=95 \% \text { MDD }\end{array}$ & Memenuhi \\
\hline Permeabilitas $\leq 10^{-5} \mathrm{~cm} / \mathrm{s}$ & $7,26 \times 10^{-7} \mathrm{~cm} /$ detik & Material bersifat permeabel & Memenuhi \\
\hline
\end{tabular}


Sebelum melakukan spesifikasi material filter halus, dilakukan penentuan terhadap batas range gradasi material filter. Tabel 2 menunjukkan hasil investigasi dari sampel material filter memenuhi kriteria untuk digunakan sebagai material timbunan filter.

Tabel 2 : Hasil Spesifikasi Material Filter Halus

\begin{tabular}{ccc}
\hline Kriteria & Hasil Investigasi & Keterangan \\
\hline \hline Material gradasi kasar & $\begin{array}{c}96,34-100 \% \text { tertahan ayakan No. 200 } \\
\text { (Pasir dan Kerikil) }\end{array}$ & Memenuhi \\
\hline $\begin{array}{c}\text { Gradasi butiran material } \\
\text { sesuai range zona filter }\end{array}$ & Masuk range zona filter & Memenuhi \\
\hline $0,10 \mathrm{~mm}<$ D15F $\leq 0,70 \mathrm{~mm}$ & $0,10 \mathrm{~mm}<\mathrm{D} 15 \mathrm{~F}=0,24 \mathrm{~mm} \leq 0,70 \mathrm{~mm}$ & Memenuhi \\
\hline D15F/D85B $<5$ & 3,15 & Memenuhi \\
\hline Dmax $<75 \mathrm{~mm}$ & $50,8 \mathrm{~mm}$ & Memenuhi \\
\hline Lolos Ayakan No.200 $<5 \%$ & $0 \%-3,66 \%$ & Memenuhi \\
\hline D15F/D15B $>5$ & 90,73 & Memenuhi \\
\hline Sifat Non Plastis & Non Plastis & Memenuhi \\
\hline $\begin{array}{c}\text { Permeabilitas } \\
\mathrm{k}>(25 \mathrm{x} \text { material inti) }\end{array}$ & $\mathrm{k}=0,00596 \mathrm{~cm} / \mathrm{s}>25 \mathrm{k}$ inti $=1,81 \times 10^{-5} \mathrm{~cm} / \mathrm{s}$ & Memenuhi \\
\hline
\end{tabular}

\subsection{Kondisi Geologi \& Perbaikan Pondasi Bendungan Semantok.}

Ditinjau dari investigasi geoteknik, berdasarkan hasil dari pemboran inti di sepanjang as bendungan ini diperoleh 3 lapisan : Pasir, Batu Pasir, dan Batu Lempung. Secara keseluruhan batuan pondasi bendungan Semantok memiliki daya dukung cukup kuat namun rembesan pada dasar tubuh bendungan patut diperhatikan.

Berdasarkan hasil trial grouting, didapatkan bahwa secara umum tidak metode ini tidak efektif. Maka direncanakan alternatif perbaikan pondasi lain. Berdasarkan risalah inspeksi dan diskusi dengan Komisi Keamanan Bendungan \& Balai Bendungan, metode Secant Pile Cut-Off Wall dan Cut-Off Trench dipilih karena dianggap paling efektif.

Penggunaan metode Secant Pile Cut-Off Wall pada Bendungan Semantok direncanakan pada sepanjang STA. $0+925$ sampai dengan STA. $2+375$, secara umum pada bentang tersebut lapisan kedap air sangat dalam. Variasi kedalaman Secant Pile Cut-Off Wall hingga 25 meter. Secant Pile direncanakan dengan diameter 0,88 meter dan overlap $20 \mathrm{~cm}$. Beton Capping direncanakan dengan Beton K225 tanpa tulangan, dengan tebal 0,70 meter dan lebar menyesuaikan dengan lebar dasar zona inti kedap air. Cut-Off Trench pada Bendungan Semantok digunakan pada STA. 0+000 hingga STA. 0+925 dan STA.2+375 hingga STA.3+100. Paritan diisi dengan material pada zona inti bendungan yang dipadatkan, agar mencapai nilai permeabilitas $10^{-8}-10^{-9} \mathrm{~cm} / \mathrm{s}$. Cut Off Trench direncanakan dengan kedalaman bervariasi hingga $10 \mathrm{~m}$, lebar dasar minimal $6 \mathrm{~m}$. Perbandingan lebar dasar dengan kedalaman paritan $\mathrm{W} / \mathrm{h}=1$.

\subsection{Tegangan Vertikal dan Daya Dukung Pondasi}

Dengan dasar pondasi bendungan terletak pada elevasi $+63,53 \mathrm{~m}$, menurut bor-log $\mathrm{BH}-$ 14, sub-layer pondasi terdiri dari: lapisan CL, D, CL, dan CM. Perhitungan total tegangan timbunan ditinjau untuk tiap layer batuan. Nilai kekuatan desain pondasi dengan memperhatikan RQD ditunjukkan pada Tabel 3. Perbandingan total tegangan timbunan dan 
kekuatan desain batuan pondasi ditunjukkan pada Tabel 4. Karena $\sigma \mathrm{z}$ total $<$ qu desain, maka batuan pondasi AMAN atau memenuhi sebagai tumpuan bendungan.

Tabel 3 : Perhitungan Daya Dukung Desain Batuan Pondasi

\begin{tabular}{ccccc}
\hline $\begin{array}{c}\text { Sub-layer } \\
\text { Batuan Pondasi }\end{array}$ & $\begin{array}{c}\text { RQD } \\
\mathbf{\%}\end{array}$ & $\begin{array}{c}\text { Kriteria Desain } \\
\text { Kekuatan Tertinggi }\end{array}$ & $\begin{array}{c}\text { qu (UCS) Tabel } \\
\mathbf{~ k g f} / \mathbf{c m}^{2}\end{array}$ & $\begin{array}{c}\mathbf{q u}(\mathbf{U C S}) \mathbf{d e s a i n} \\
\mathbf{k g f} / \mathbf{c m}^{2}\end{array}$ \\
\hline El. +63,53 (CL) & 0 & $15 \%$ nilai UCS & 200 or less & 30 \\
El. +62,03 (D) & 0 & $15 \%$ nilai UCS & 200 or less & 30 \\
El. +55,03 (CL) & $0-29$ & $15 \%$ nilai UCS & 200 or less & 30 \\
El.+47,03 (CM) & $22-73$ & $15 \%$ nilai UCS & $400-200$ & $60-30$ \\
\hline
\end{tabular}

Tabel 4 : Perbandingan Tegangan Vertikal terhadap Daya Dukung Batuan Pondasi

\begin{tabular}{ccccc}
\hline Sub-layer Batuan Pondasi & $\begin{array}{c}\text { qu (UCS) desain } \\
\mathbf{k g f} / \mathbf{c m}^{\mathbf{2}}\end{array}$ & $\begin{array}{c}\mathbf{\sigma z} \text { total } \\
\mathbf{k g f} / \mathbf{c m}^{\mathbf{2}}\end{array}$ & \multicolumn{2}{c}{ Kondisi Daya Dukung Batuan } \\
\hline CL & 30 & 4,376 & $\sigma \mathrm{z}$ total $<$ qu desain & AMAN \\
D & 30 & 4,327 & $\sigma \mathrm{z}$ total $<$ qu desain & AMAN \\
CL & 30 & 4,128 & $\sigma \mathrm{z}$ total $<$ qu desain & AMAN \\
CM & $60-30$ & 3,909 & $\sigma \mathrm{z}$ total $<$ qu desain & AMAN \\
\hline
\end{tabular}

\subsection{Penurunan Zona Inti Bendungan}

Adanya proses konsolidasi menyebabkan penurunan pada zona inti pada tubuh bendungan. Diketahui data sebagai berikut:

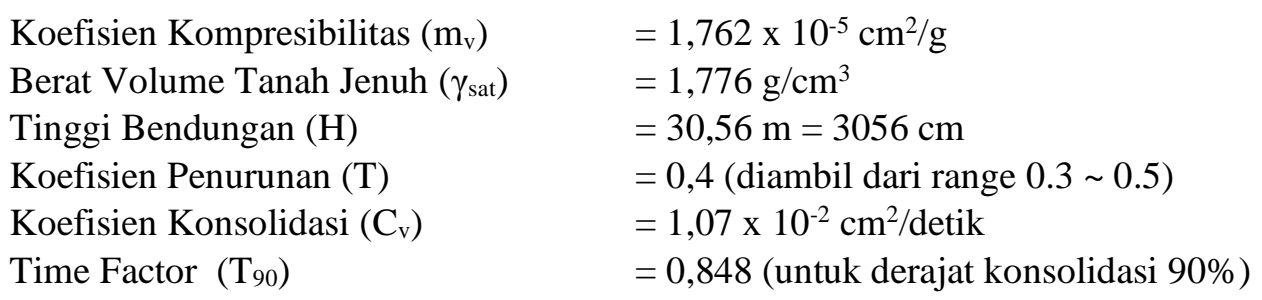

Besarnya penurunan $(\Delta \mathrm{H})$ pada zona inti Bendungan Semantok adalah sebagai berikut:

$E=\frac{1}{m v}=\frac{1}{\left(1,762 \times 10^{-5}\right)}=56753,69 \mathrm{~g} / \mathrm{cm}^{2}$

$\Delta H=\frac{1}{2 E} \cdot \gamma \cdot H^{2} \cdot T=\frac{1}{2 \cdot 56753.69} \cdot 1,776 \cdot 3056^{2} \cdot 0,4=58,45 \mathrm{~cm}=0,585 \mathrm{~m}$

Sedangkan waktu penurunan yang diperlukan untuk konsolidasi 90\% sebesar:

$t=\frac{T_{90} \cdot H^{2}}{C v}=\frac{0,848 \times 3056^{2}}{1,07 \times 10^{-2}}=738491917,9$ detik $=23,42$ tahun

Dengan demikian maka prosentase penurunan bendungan Semantok sebesar:

Prosentase $=\frac{\Delta H}{H} \cdot 100 \%=\frac{0,585}{30,56} \cdot 100 \%=1,91 \%$

Karena nilai penurunan $=1,91 \%<$ batas ijin 3\%, maka Bendungan Semantok dapat dikatakan AMAN terhadap penurunan (settlement). 


\subsection{Penurunan Elastis Tanah Pondasi}

Dengan diketahui adanya 3 sub-layer pondasi di bawah Bendungan Semantok, yaitu pasir, batu pasir, dan batu lempung, diperkirakan dapat terjadi penurunan tanah elastis . Penurunan tanah elastis terjadi pada tanah yang kompresibel. Diketahui :

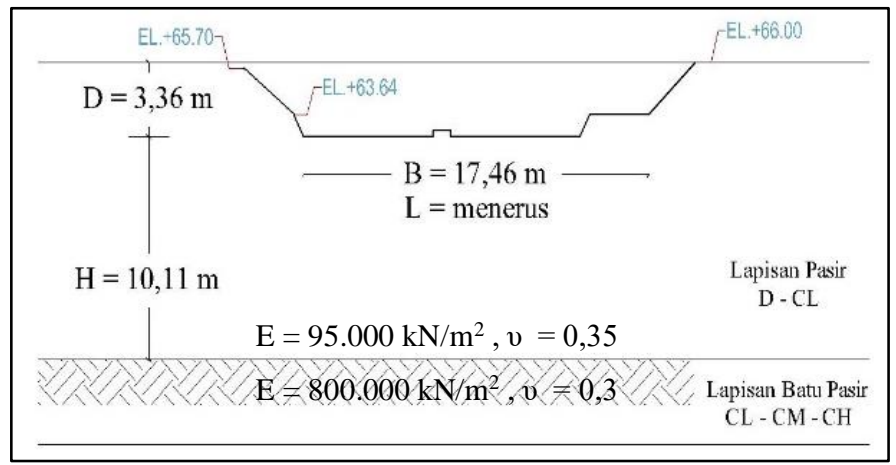

Gambar 3 : Skema Sub-layer Pondasi

$\begin{array}{ll}\text { Jenis pondasi } & =\text { Fleksibel } \\ \text { Tegangan pondasi (q) } & =429,18 \mathrm{kN} / \mathrm{m}^{2} \\ \text { Lebar pondasi (B) } & =17,46 \mathrm{~m} \\ \text { Modulus Young (E) } & =95000 \mathrm{kN} / \mathrm{m}^{2} \\ \text { Poisson's Ratio (v) } & =0,35 \\ \text { Panjang pondasi (L) } & =\infty(\text { menerus) } \\ \text { Kedalaman pondasi (D) } & =3,36 \mathrm{~m} \\ \text { Jarak ke lapisan keras }(\mathrm{H}) & =10,11 \mathrm{~m}\end{array}$

Deformasi elastis dengan Metode Compressible layer on a rigid base menggunakan pendekatan penurunan (Scleicher) didapatkan sebesar 3,56 cm. Sementara deformasi elastis dengan pendekatan Penurunan (Lord) didapatkan sebesar 4,36 cm.

\subsection{Kapasitas Aliran Filtrasi}

Input parameter untuk simulasi SEEP/W ditunjukkan pada Tabel 5. Dengan program SEEP/W Geo-Studio 2018 didapatkan pola garis freatik pada kondisi Muka Air Minimum (MAM), Muka Air Normal (MAN), Muka Air Banjir (MAB), dan Surut Cepat (Rapid Drawdown).

Tabel 5 : Perhitungan Nilai Permeabilitas Material Bendungan Semantok

\begin{tabular}{cccc}
\hline Material & $\mathrm{K}(\mathrm{m} / \mathrm{s})$ & $\mathrm{mv}(\mathrm{kPa})$ & Material Model \\
\hline \hline Inti Kedap Air & $1,62 \mathrm{E}-08$ & $1,76 \mathrm{E}-05$ & Saturated/Unsaturated \\
Filter Halus & $5,96 \mathrm{E}-05$ & 0 & Saturated/Unsaturated \\
Transisi & $1,00 \mathrm{E}-05$ & 0 & Saturated/Unsaturated \\
Random Tanah & $7,58 \mathrm{E}-07$ & 0 & Saturated/Unsaturated \\
Rip-rap & $1,00 \mathrm{E}-02$ & 0 & Saturated/Unsaturated \\
Beton Capping & $1,00 \mathrm{E}-11$ & 0 & Saturated Only \\
Beton Plastis & $1,00 \mathrm{E}-10$ & 0 & Saturated Only \\
Pondasi Pasir & $6,78 \mathrm{E}-06$ & 0 & Saturated Only \\
Pondasi Batu Pasir & $5,00 \mathrm{E}-07$ & 0 & Saturated Only \\
Pondasi Batu Lempung & $6,62 \mathrm{E}-09$ & 0 & Saturated Only \\
\hline
\end{tabular}


Dengan SEEP/W didapatkan nilai flux dan flow rate pada masing-masing kondisi. Diketahui debit rerata sungai Semantok $1,13 \mathrm{~m}^{3} / \mathrm{s}$. Rembesan bendungan tidak boleh melebihi $1 \%$ dari limpasan tahunan rata-rata Sungai Semantok. Sehingga $1,13 \mathrm{~m}^{3} / \mathrm{s}$ x $1 \%$ $=0,0113 \mathrm{~m}^{3} / \mathrm{s}$. Nilai debit rembesan Sungai Semantok ditunjukkan pada Tabel 6 . Didapatkan hasil debit rembesan pada berbagai kondisi $<1 \%$ debit rerata sungai, dengan demikian Bendungan Semantok AMAN terhadap rembesan.

Tabel 6 : Rekapitulasi Debit Rembesan pada Berbagai Kondisi

\begin{tabular}{ccccc}
\hline Kondisi & $\begin{array}{c}\text { Water Rate } \\
\left(\mathrm{m}^{3} / \mathrm{dtk} / \mathrm{m}\right)\end{array}$ & $\begin{array}{c}\text { Panjang } \\
\text { Bendungan } \\
(\mathrm{m})\end{array}$ & $\begin{array}{c}\text { Q Rembesan } \\
(\text { Flow Rate } \times \text { Panjang }) \\
\left(\mathrm{m}^{3} / \text { detik }\right)\end{array}$ & Kete-rangan \\
\hline \hline M.A.B $(+93,31)$ & $6,55 \times 10^{-7}$ & 3.005 & $1,97 \times 10^{-3}$ & AMAN \\
M.A.N $(+90,14)$ & $2,17 \times 10^{-7}$ & 3.005 & $6,52 \times 10^{-4}$ & AMAN \\
M.A.M (+78,64) & $9,86 \times 10^{-8}$ & 3.005 & $2,96 \times 10^{-4}$ & AMAN \\
Rapid Draw Down & $2,78 \times 10^{-7}$ & 3.005 & $8,36 \times 10^{-4}$ & AMAN \\
\hline
\end{tabular}

\subsection{Gejala Buluh (Piping) dan Sembulan (Boiling)}

Nilai kecepatan rembesan didapatkan dari water flux di hilir tumit inti kedap air dengan SEEP/W Geo-Studio 2018, pada Kondisi Muka Air Normal (MAN) +90,14 m. Berdasarkan hasil simulasi didapat nilai kecepatan rembesan (Vs) sebesar 8,58 x 10-8 $\mathrm{m} /$ detik. Diketahui data sebagai berikut:

$$
\begin{array}{ll}
\text { D50 (Zona Inti) } & =0,0053 \mathrm{~mm}=0,00053 \mathrm{~cm} \\
\text { Spesific Gravity }(\mathrm{Gs}) & =2,626 \\
\text { Angka pori }(\mathrm{e}) & =1,15 \\
\text { Berat Volume Air }\left(\gamma_{\mathrm{w}}\right) & =1 \mathrm{~g} / \mathrm{cm}^{3} \\
\text { Gravitasi }(\mathrm{g}) & =981 \mathrm{~cm} / \text { detik }^{2}
\end{array}
$$

Sementara nilai kecepatan kritis dihitung sebagai berikut:

$$
\begin{aligned}
& W_{1}=\frac{(G s-1) \cdot \gamma_{w}}{1+e} \cdot \frac{4}{3} \pi r^{3}=\frac{(2,626-1) \cdot 1}{1+1,15} \cdot \frac{4}{3} \pi 0,00053^{3}=3,96 \cdot 10^{-10} \mathrm{~g} \\
& F=\frac{\pi}{4} \cdot d^{2}=\frac{\pi}{4} \cdot 0,0172^{2}=7,85 \cdot 10^{-7} \mathrm{~cm}^{2} \\
& V c \quad=\sqrt{\frac{W 1 \times g}{F x \gamma w}}=\sqrt{\frac{3,96 \cdot 10^{-10} \times 981}{7,85 \cdot 10^{-7} \times 1}}=0,703 \mathrm{~cm} / \text { detik }=7,03 \times 10^{-3} \mathrm{~m} / \text { detik }
\end{aligned}
$$

Karena Vs $<$ Vc, dengan demikian dapat dinyatakan bahwa Bendungan Semantok AMAN terhadap gejala piping ditinjau dari kecepatan rembesan.

Nilai hydraulic gradient. juga didapatkan dari analisa dengan SEEP/W Geo-Studio 2018 pada Kondisi Muka Air Normal (MAN) +90,14 m. Hydraulic gradient ditinjau pada tumit hilir inti bendungan, dengan material inti bendungan merupakan material lempung yang memiliki nilai kohesi. Karena material yang ditinjau merupakan lempung, maka nilai gradien kritis sangat besar, dan potensi boiling menjadi sangat kecil. Dengan demikian dapat dinyatakan bahwa Bendungan Semantok AMAN terhadap gejala boiling ditinjau dari gradien hidraulik. 


\subsection{Penentuan Beban Gempa}

Dengan nilai Faktor Resiko Total $=34$, Bendungan Semantok termasuk dalam Kelas Resiko IV (Ekstrem). Dengan kelas resiko IV (Ekstrem), stabilitas bendungan dengan beban gempa akan dianalisa dengan persyaratan tanpa kerusakan (MDE) pada Kala Ulang 100 Tahun dan 200 Tahun, serta persyaratan diperkenankan kerusakan tanpa keruntuhan (OBE) pada Kala Ulang 10.000 tahun. Nilai percepatan batuan dasar (SB) didapat dari Peta Gempa 2017. Hasil perhitungan koefisien gempa ditunjukkan pada Tabel 7.

\section{Tabel 7 : Perhitungan Koefisien Gempa}

\begin{tabular}{|c|c|c|c|c|c|c|c|c|c|}
\hline \multirow{2}{*}{$\begin{array}{c}\text { Periode } \\
\text { Ulang (T) } \\
\text { (tahun) }\end{array}$} & \multirow{2}{*}{$\begin{array}{l}\text { SB } \\
(\mathrm{g}) \\
\end{array}$} & \multirow{2}{*}{$\mathrm{F}_{\mathrm{PGA}}$} & \multirow{2}{*}{$\begin{array}{c}\text { PGAM } \\
(\mathrm{g})\end{array}$} & \multirow{2}{*}{$\mathrm{Kh}$} & \multirow{2}{*}{ Ko } & \multicolumn{4}{|c|}{$\mathrm{k}$} \\
\hline & & & & & & $\mathrm{Y}=0,25 \mathrm{H}$ & $\mathrm{Y}=0,5 \mathrm{H}$ & $\mathrm{Y}=0,75 \mathrm{H}$ & $\mathrm{Y}=\mathrm{H}$ \\
\hline 100 & 0,098 & 1 & 0,098 & 0,10 & 0,05 & 0,10 & 0,08 & 0,077 & 0,07 \\
\hline 200 & 0,138 & 1 & 0,138 & 0,14 & 0,07 & 0,14 & 0,12 & 0,11 & 0,10 \\
\hline 10000 & 0,518 & 1 & 0,518 & 0,54 & 0,26 & 0,54 & 0,45 & 0,41 & 0,37 \\
\hline
\end{tabular}

\subsection{Stabilitas Lereng Bendungan dengan SLOPE/W GeoStudio 2018}

Input yang diperlukan pada program ini antara lain geometri bendungan, karakteristik material, dan koefisien gempa. Input karakteristik material ditunjukkan pada Tabel 8. Input koefisien gempa ditunjukkan pada Tabel 9. Kemudian Faktor Keamanan yang didapat dari simulasi dibandingkan dengan kriteria Faktor Keamanan minimum.

Tabel 8 : Input Key-In Material pada SLOPE/W Geo-Studio 2018

\begin{tabular}{clccccc}
\hline Zona & Material Model & $\begin{array}{c}\gamma_{\text {dry }} \\
\mathrm{kN} / \mathrm{m}^{3}\end{array}$ & $\begin{array}{c}\gamma_{\text {wet }} \\
\mathrm{kN} / \mathrm{m}^{3}\end{array}$ & $\begin{array}{c}\gamma_{\mathrm{sat}} \\
\mathrm{kN} / \mathrm{m}^{3}\end{array}$ & $\begin{array}{c}\mathrm{C} \\
\mathrm{kPa}\end{array}$ & $\begin{array}{c}\varphi \\
\circ\end{array}$ \\
\hline Inti Kedap Air & Mohr - Coloumb & 12,194 & 16,589 & 17,423 & 28,341 & 19 \\
Filter Halus & Mohr - Coloumb & 13,665 & 15,578 & 18,708 & 0,000 & 34 \\
Transisi & Mohr - Coloumb & 16,030 & 20,993 & 21,258 & 0,000 & 35 \\
Random Tanah & Mohr - Coloumb & 11,125 & 15,402 & 16,500 & 39 & 20 \\
Rip-rap & Mohr - Coloumb & 19,228 & 22,946 & 22,347 & 0,000 & 40 \\
Beton Capping & Mohr - Coloumb & 0,000 & 0,000 & 21,580 & 0,000 & 0 \\
Beton Plastis & Mohr - Coloumb & 0,000 & 0,000 & 29,430 & 0,000 & 0 \\
Pondasi Pasir & Mohr - Coloumb & 0,000 & 0,000 & 18,149 & 0,000 & 36 \\
Pondasi Batu Pasir & Mohr - Coloumb & 0,000 & 0,000 & 18,639 & 1,069 & 36 \\
Pondasi Batu Lempung & Mohr - Coloumb & 0,000 & 0,000 & 17,658 & 2,943 & 24 \\
\hline
\end{tabular}

Tabel 9 : Input Parameter Seismic Load pada SLOPE/W Geo-Studio 2018

\begin{tabular}{ccccccccc}
\hline \multirow{2}{*}{ Kala Ulang Gempa } & \multicolumn{2}{c}{$\mathrm{Y}=0,25 \mathrm{H}$} & \multicolumn{2}{c}{$\mathrm{Y}=0,5 \mathrm{H}$} & \multicolumn{2}{c}{$\mathrm{Y}=0,75 \mathrm{H}$} & \multicolumn{2}{c}{$\mathrm{Y}=1 \mathrm{H}$} \\
& $\mathrm{kh}$ & $\mathrm{kv}$ & $\mathrm{kh}$ & $\mathrm{kv}$ & $\mathrm{kh}$ & $\mathrm{kv}$ & $\mathrm{kh}$ & $\mathrm{kv}$ \\
\hline \hline OBE 100 tahun & 0,10 & 0,05 & 0,08 & 0,04 & 0,077 & 0,0385 & 0,07 & 0,035 \\
OBE 200 tahun & 0,14 & 0,07 & 0,12 & 0,06 & 0,11 & 0,055 & 0,10 & 0,05 \\
MDE 10000 tahun & 0,54 & 0,27 & 0,45 & 0,225 & 0,41 & 0,205 & 0,37 & 0,185 \\
\hline
\end{tabular}

Dengan program SLOPE/W GeoStudio 2018 didapatkan nilai angka keamanan dan bidang gelincir untuk bagian hulu dan hilir bendungan sesuai kondisi bendungan dan faktor beban gempa. Rekapitulasi hasil analisa ditampilkan pada Tabel 10. 
Tabel 10 :Rekapitulasi FK Stabilitas Lereng Bendungan Semantok

\begin{tabular}{|c|c|c|c|c|c|c|c|c|c|c|}
\hline \multicolumn{2}{|c|}{ Kondisi yang Ditinjau } & \multicolumn{4}{|c|}{ Hulu } & \multicolumn{4}{|c|}{ Hilir } & FK ijin \\
\hline \multirow{5}{*}{ 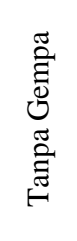 } & Setelah Konstruksi & \multicolumn{4}{|c|}{2,202} & \multicolumn{4}{|c|}{2,291} & 1,5 \\
\hline & MAB & \multicolumn{4}{|c|}{2,201} & \multicolumn{4}{|c|}{2,179} & 1,3 \\
\hline & MAN & \multicolumn{4}{|c|}{2,201} & \multicolumn{4}{|c|}{2,291} & 1,5 \\
\hline & MAM & \multicolumn{4}{|c|}{2,198} & \multicolumn{4}{|c|}{2,291} & 1,3 \\
\hline & Surut Cepat & \multicolumn{4}{|c|}{1,944} & \multicolumn{4}{|c|}{2,291} & 1,1 \\
\hline \multirow{2}{*}{\multicolumn{2}{|c|}{ Kondisi yang Ditinjau }} & \multicolumn{4}{|c|}{ Hulu } & \multicolumn{4}{|c|}{ Hilir } & \multirow[b]{2}{*}{ FK ijin } \\
\hline & & $\begin{array}{c}\mathrm{y} / \mathrm{h} \\
0,25\end{array}$ & $\begin{array}{c}\mathrm{y} / \mathrm{h} \\
0,50\end{array}$ & $\begin{array}{c}\mathrm{y} / \mathrm{h} \\
0,75\end{array}$ & $\begin{array}{c}\mathrm{y} / \mathrm{h} \\
1 \\
\end{array}$ & $\begin{array}{c}\mathrm{y} / \mathrm{h} \\
0,25 \\
\end{array}$ & $\begin{array}{c}\mathrm{y} / \mathrm{h} \\
0,50\end{array}$ & $\begin{array}{c}\mathrm{y} / \mathrm{h} \\
0,75 \\
\end{array}$ & $\begin{array}{c}\mathrm{y} / \mathrm{h} \\
1 \\
\end{array}$ & \\
\hline \multirow{5}{*}{ 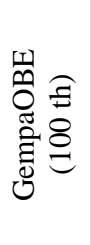 } & Setelah Konstruksi & 1,662 & 1,747 & 1,76 & 1,792 & 1,755 & 1,84 & 1,854 & 1,886 & 1,2 \\
\hline & MAB & 1,396 & 1,503 & 1,521 & 1,564 & 1,591 & 1,683 & 1,697 & 1,732 & 1,1 \\
\hline & MAN & 1,396 & 1,503 & 1,521 & 1,564 & 1,738 & 1,836 & 1,851 & 1,886 & 1,2 \\
\hline & MAM & 1,396 & 1,503 & 1,521 & 1,564 & 1,755 & 1,84 & 1,854 & 1,886 & 1,1 \\
\hline & Surut Cepat & 1,326 & 1,413 & 1,428 & 1,462 & 1,755 & 1,84 & 1,854 & 1,886 & 1,1 \\
\hline \multirow{5}{*}{ 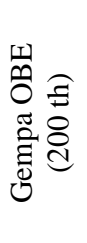 } & Setelah Konstruksi & 1,517 & 1,586 & 1,623 & 1,67 & 1,607 & 1,678 & 1,716 & 1,763 & 1,2 \\
\hline & MAB & 1,225 & 1,304 & 1,348 & 1,406 & 1,437 & 1,510 & 1,549 & 1,600 & 1,1 \\
\hline & MAN & 1,225 & 1,304 & 1,348 & 1,406 & 1,563 & 1,645 & 1,690 & 1,747 & 1,2 \\
\hline & MAM & 1,225 & 1,304 & 1,348 & 1,406 & 1,608 & 1,678 & 1,716 & 1,763 & 1,1 \\
\hline & Surut Cepat & 1,183 & 1,250 & 1,287 & 1,334 & 1,597 & 1,676 & 1,716 & 1,763 & 1,1 \\
\hline \multirow{5}{*}{ 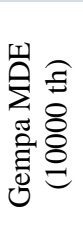 } & Setelah Konstruksi & 0,837 & 0,926 & 0,972 & 1,025 & 0,872 & 0,967 & 1,017 & 1,073 & 1 \\
\hline & MAB & 0,589 & 0,659 & 0,697 & 0,741 & 0,766 & 0,848 & 0,893 & 0,943 & 1 \\
\hline & MAN & 0,589 & 0,659 & 0,697 & 0,741 & 0,808 & 0,898 & 0,947 & 1,003 & 1 \\
\hline & MAM & 0,589 & 0,659 & 0,697 & 0,741 & 0,873 & 0,968 & 1,018 & 1,075 & 1 \\
\hline & Surut Cepat & 0,585 & 0,655 & 0,693 & 0,737 & 0,832 & 0,927 & 0,979 & 1,037 & 1 \\
\hline
\end{tabular}

Berdasarkan hasil tersebut, stabilitas lereng kondisi tanpa gempa, dengan gempa OBE 100 tahun, dan gempa OBE 200 tahun memenuhi FK ijin atau AMAN. Sementara kondisi Gempa MDE 10.000 tahun tidak memenuhi FK ijin atau TIDAK AMAN.

\subsection{Analisa Alihan Tetap / Deformasi Permanen}

Berdasarkan nilai FK pada Gempa MDE yang tidak memenuhi kriteria, maka perlu dilanjutkan dengan analisa alihan tetap / deformasi permanen. Dengan diketahui:

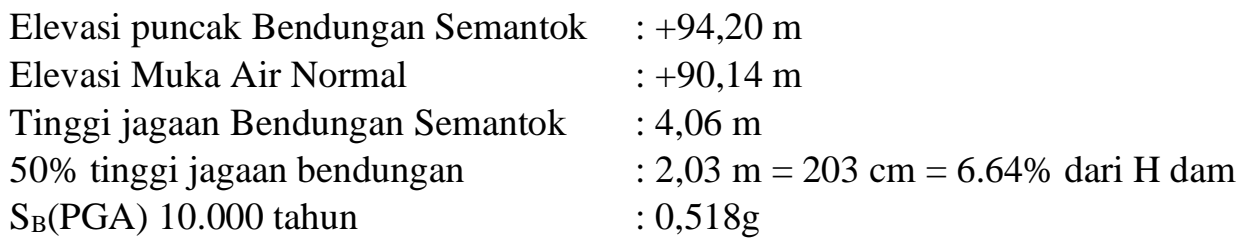

Berdasarkan hasil plotting analisa Metode Makdisi \& Seed pada Gambar 4(a) didapat nilai maksimum penurunan $114 \mathrm{~cm}$. Sementara hasil plotting Metode Swaisgood pada Gambar 4(b) didapat nilai maksimum penurunan adalah 0,858\% dari $\mathrm{H}$ dam. Kedua nilai tersebut < nilai ijin (50\% tinggi jagaan) $203 \mathrm{~cm}$. Sehingga dapat disimpulkan bahwa pada kondisi Gempa MDE 10.000 tahun Bendungan Semantok masih AMAN. 


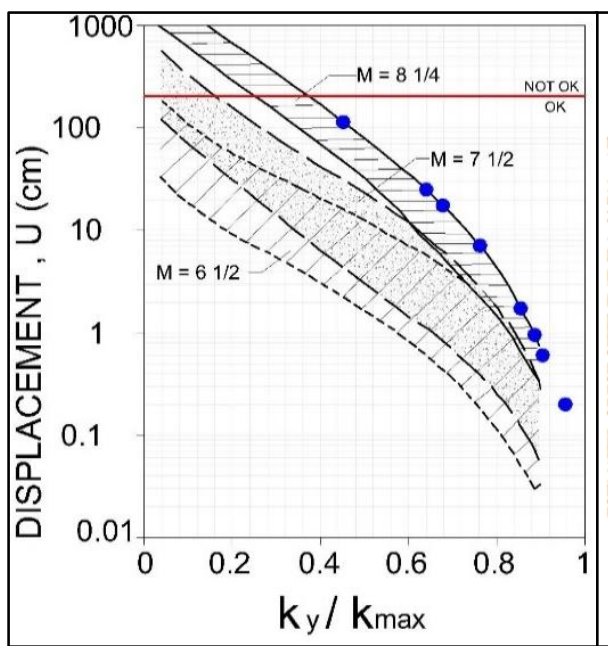

(a)

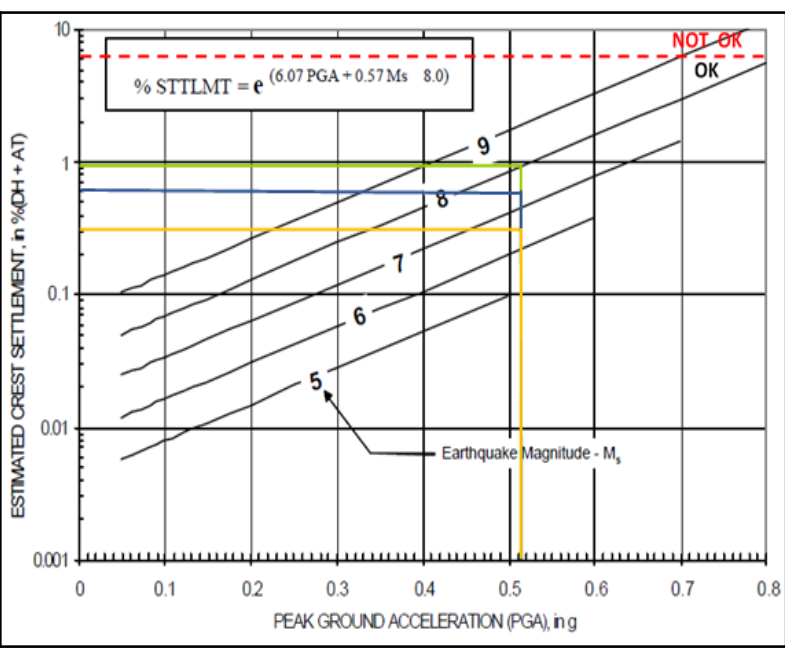

(b)

Gambar 4 : Plotting pada Grafik Hubungan ky/km dan Displacement Makdisi \& Seed (a) dan Plotting pada Grafik Hubungan PGA, Ms dan Settlement Swaisgood (b)

\section{Kesimpulan}

Spesifikasi material inti kedap air dan material filter halus ditinjau dari gradasi dan sifat material telah memenuhi kriteria untuk sesuai pedoman dan referensi yang ada.

Secara umum kondisi geoteknik Bendungan Semantok cukup padat, namun rembesan cukup besar. Hasil trial grouting dinilai tidak efektif, alternatif perbaikan pondasi direncanakan Secant Pile Cut-Off Wall dan Cut-Off Trench.

Daya dukung batuan pondasi Bendungan Semantok aman dan memenuhi sebagai tumpuan bendungan. Material zona inti Bendungan Semantok aman terhadap penurunan (settlement). Sementara penurunan tanah elastis pada lapisan kompresibel pondasi Bendungan Semantok relatif sangat kecil .

Besar kapasitas aliran filtrasi atau debit rembesan Bendungan Semantok aman. Kecepatan rembesan Bendungan Semantok aman dari gejala buluh (piping). Gradien hidraulik Bendungan Semantok aman dari gejala sembulan (boiling).

Pada kondisi tanpa gempa, kondisi dengan gempa OBE 100 tahun, OBE 200 tahun, stabilitas lereng Bendungan Semantok aman. Pada kondisi gempa MDE 10.000 tahun stabilitas lereng Bendungan Semantok tidak aman. Tetapi untuk kondisi gempa MDE 10.000 tahun Bendungan Semantok aman terhadap deformasi permanen/alihan tetap.

\section{Ucapan Terimakasih}

Penulis mengucapkan terimakasih atas akses data dalam studi terkait Bendungan Semantok ini kepada Satuan Kerja Bendungan BBWS Brantas, Balai Kegiatan Pembangunan Bendungan Nganjuk BBWS Brantas, serta Konsultan Supervisi PT. Caturbina Guna Persada (JO), PT. Arga Pasca Rencana, dan PT. Wecon. 


\section{Daftar Pustaka}

[1] Kementrian PUPR, Rencana Strategis Kementrian PUPR Tahun 2015-2019, Jakarta, 2015.

[2] A. Nugroho, "Progres semantok baru tujuh persen bbws sebut ada perubahan desain", Jawa Pos : Radar Kediri, 28 Mei 2019. [Online]. Tersedia : https://radarkediri.jawapos.com/read/2019/05/28/139238/progres-semantok-barutujuh-persen [Diakses 3 Juli 2019].

[3] Supervisi Bendungan Semantok, "Justifikasi Teknis Perubahan Desain Perbaikan Pondasi Bendungan Semantok”, Nganjuk, 2019.

[4] Ditjen Pengairan, Panduan Perencanaaan Bendungan Urugan, vol. III, 1999.

[5] USBR, " Chapter 5 protective filters" in Design Standards No.13 Embankment Dams, Amerika: U.S. Department of The Interior Bureau of Reclamation, 2014.

[6] S. Sosrodarsono dan K. Takeda, Bendungan Tipe Urugan, Jakarta: PT. Pradnya Paramita, 2016.

[7] S. Sosrodarsono dan K. Nakazawa, Mekanika Tanah dan Teknik Pondasi, Jakarta: PT. Pradnya Paramita, 1987.

[8] JICA, Preparatory Survey On Moragahakanda Development Project Final Report, vol. II, Sri Lanka : Nippon Koei, 2010.

[9] American Society of Civil Engineers, Minimum Design Loads for Building and Other Structures, Amerika, 2013.

[10] D. Willye, Foundations on Rock. New York: Routledge, 1999.

[11] M. Tomlinson, Foundation and Design Construction 7th Edition, Inggris: Pearson Education, 2001.

[12] Departemen Pekerjaan Umum, Pedoman Grouting untuk Bendungan, Jakarta, 2005.

[13] R. Asmaranto et.al, "Safety evaluation of the existing Grawan dam based on hydrogeotechnical behaviour conditions to ensure the availability of water resources", IOP Conference Series: Earth and Environmental Science, 2020.

[14] Soedibyo, Teknik Bendungan, Jakarta: PT. Pradnya Paramita, 2003.

[15] R. F. Craig \& B. Susilo, Mekanika Tanah, Jakarta: Erlangga, 1989.

[16] Depkimpraswil, Analisis Stabilitas Bendungan Tipe Urugan akibat Beban Gempa, 2004.

[17] Pusat Studi Gempa Nasional, Peta Sumber dan Bahaya Gempa Tahun 2017, Bandung: Puslitbang Perumahan dan Permukiman Kementrian PUPR, 2017.

[18] Badan Standardisasi Nasional, Metode Analisis Stabilitas Lereng Statik Bendungan Tipe Urugan, Jakarta: Badan Standardisasi Nasional, 2016. 
[19] J. Bray, "Simplified seismic slope displacement procedures", Pitilakis K.D. (eds) Earthquake Geotechnical Engineering, 2007.

[20] F. Makdisi \& H.B. Seed, A Simplified Procedure For Estimating EarthquakeInduced Deformations In Dams And Embankments, Berkeley: University of California, 1977.

[21] J. Swaisgood, "Embankment dam deformations caused by earthquakes", Pacific Conference on Earthquake Engineering, 2003. 